\title{
Experimental investigation and characterization of façade integrated pvt collectors with and without insulation
}

Dannemand, Mark; Sifnaios, loannis; Jensen, Adam Rasmus; Furbo, Simon

Link to article, DOI:

10.18086/swc.2019.35.02

Publication date:

2019

Document Version

Publisher's PDF, also known as Version of record

Link back to DTU Orbit

Citation (APA):

Dannemand, M., Sifnaios, I., Jensen, A. R., \& Furbo, S. (2019). Experimental investigation and characterization of façade integrated pvt collectors with and without insulation. Paper presented at ISES Solar World Congress 2019 and IEA SHC conference 2019, Santiago, Chile. https://doi.org/10.18086/swc.2019.35.02

\section{General rights}

Copyright and moral rights for the publications made accessible in the public portal are retained by the authors and/or other copyright owners and it is a condition of accessing publications that users recognise and abide by the legal requirements associated with these rights.

- Users may download and print one copy of any publication from the public portal for the purpose of private study or research

- You may not further distribute the material or use it for any profit-making activity or commercial gain

- You may freely distribute the URL identifying the publication in the public portal 


\title{
EXPERIMENTAL INVESTIGATION AND CHARACTERIZATION OF FAÇADE INTEGRATED PVT COLLECTORS WITH AND WITHOUT INSULATION
}

\author{
Mark Dannemand, Ioannis Sifnaios, Adam R. Jensen, Simon Furbo
}

Department of Civil Engineering, Technical University of Denmark (DTU), Kgs. Lyngby, Denmark

\begin{abstract}
The performance of two unglazed aluminum PVT collectors integrated into a concrete wall was investigated in a laboratory test facility. One PVT collector was installed in direct contact with the concrete wall and the other was installed with $10 \mathrm{~mm}$ of Styrofoam between the PVT collector and the wall. It was found that the temperatures of the walls behind the PVT collectors had big impacts on the thermal performance of the collectors. For this reason, an extended version of the traditional QDT formula was suggested for façade integrated collectors, where the effect of the temperature of the wall was also taken into account.
\end{abstract}

Keywords: Building integrated, PVT, experimental investigations, Quasi-dynamic test method.

Nomenclature and symbols

\begin{tabular}{|c|c|c|}
\hline Quantity & Symbol & Unit \\
\hline Gross area of collector & $\mathrm{A}_{\mathrm{G}}$ & $\mathrm{m}^{2}$ \\
\hline Heat loss coefficient & $\alpha_{1}$ & $\mathrm{~W} \mathrm{~m}^{-2} \mathrm{~K}^{-1}$ \\
\hline Temperature dependence of heat loss coefficient & $\alpha_{2}$ & $\mathrm{~W} \mathrm{~m}^{-2} \mathrm{~K}^{-2}$ \\
\hline Wind speed dependence of heat loss coefficient & $\alpha_{3}$ & $\mathrm{~J} \mathrm{~m}^{-3} \mathrm{~K}^{-1}$ \\
\hline Sky temperature dependence of heat loss coefficient & $\alpha_{4}$ & - \\
\hline Effective thermal capacity & $\alpha_{5}$ & $\mathrm{~J} \mathrm{~m}^{-2} \mathrm{~K}^{-1}$ \\
\hline Wind speed dependence of peak collector efficiency & $\alpha_{6}$ & $\mathrm{~m}^{-1} \mathrm{~s}$ \\
\hline Wind speed dependence of infrared radiation exchange & $\alpha_{7}$ & $\mathrm{~W} \mathrm{~m}^{-2} \mathrm{~K}^{-4}$ \\
\hline Radiation losses & $\alpha_{8}$ & $\mathrm{~W} \mathrm{~m}^{-2} \mathrm{~K}^{-4}$ \\
\hline Heat loss coefficient to the wall & $\alpha_{9}$ & $\mathrm{~W} \mathrm{~m}^{-2} \mathrm{~K}^{-1}$ \\
\hline Stefan- Boltzmann constant & $\sigma$ & $\mathrm{W} \mathrm{m}^{-2} \mathrm{~K}^{-4}$ \\
\hline Longwave irradiance & $\mathrm{E}_{\mathrm{L}}$ & $\mathrm{W} \mathrm{m}^{-2}$ \\
\hline Hemispherical solar irradiance & G & $\mathrm{W} \mathrm{m}^{-2}$ \\
\hline Global solar irradiance at the collector plane & $\mathrm{G}_{\mathrm{t}}$ & $\mathrm{W} \mathrm{m}^{-2}$ \\
\hline Beam irradiance & $\mathrm{G}_{\mathrm{b}}$ & $\mathrm{W} \mathrm{m}^{-2}$ \\
\hline Diffuse irradiance & $\mathrm{G}_{\mathrm{d}}$ & $\mathrm{W} \mathrm{m}^{-2}$ \\
\hline Incidence angle modifier for diffuse solar radiation & $\mathrm{K}_{\mathrm{d}}$ & - \\
\hline Incidence angle modifier for direct solar irradiance & $\mathrm{K}_{\mathrm{b}}$ & - \\
\hline Incidence angle modifier & $\mathrm{K}_{\vartheta}$ & - \\
\hline Incidence angle modifier coefficient & $\mathrm{b}_{0}$ & - \\
\hline Air speed & $\mathrm{u}$ & $\mathrm{m} \mathrm{s}^{-1}$ \\
\hline Reduced air speed & u' & $\mathrm{m} \mathrm{s}^{-1}$ \\
\hline Peak collector efficiency based on $\mathrm{G}_{\mathrm{b}}$ & $\eta_{0, \mathrm{~b}}$ & - \\
\hline Mean temperature of heat transfer fluid & $\vartheta_{\mathrm{m}}$ & ${ }^{\circ} \mathrm{C}$ \\
\hline Ambient air temperature & $\vartheta_{\alpha}$ & ${ }^{\circ} \mathrm{C}$ \\
\hline Wall temperature & $\vartheta_{w}$ & ${ }^{\circ} \mathrm{C}$ \\
\hline Incidence angle & $\theta_{\mathrm{i}}$ & $\circ$ \\
\hline Transversal angle of incidence & $\theta_{\mathrm{T}}$ & $\circ$ \\
\hline
\end{tabular}

\section{Introduction}

Photovoltaics (PV) panels convert solar irradiance to electricity, but their efficiency drops proportionally as the temperature of the cells increases. Solar thermal collectors convert solar irradiation into heat, which can be used for domestic applications (e.g. space heating, domestic hot water). Photovoltaic Thermal (PVT) collectors are hybrid panels combining PV and solar thermal components into a single module in order to produce electricity and useable heat simultaneously (Kramer and Helmers, 2013). The thermal component of the PVT 
collector has the potential to cool the PV component leading to higher electricity production while producing heat at the same time (Aste et al., 2014). This leads to a better utilization of the installation area, potentially reducing at the same time the use of materials, as less materials are needed to manufacture PVT collectors compared to the material use for separate PV- and thermal- panels (Dannemand et al., 2019). PVT technology has been investigated and considered favorable for domestic applications (e.g. heating, cooling, electricity etc.) (Butera et al., 2007). Integrating PVT collectors into the roof or façade of a building allows also for synergetic effects in terms of reducing the construction materials used and increasing aesthetics of the building.

The aim of this investigation was to determine the performance potential of PVT collectors mounted on a concrete wall with and without a layer of insulation between the PVT collector and the wall. It was expected that the insulation would influence the performance of the panel, since the thermal mass of the building construction that is in contact with the PVT panel would affect the panel's power production.

\section{Methodology}

Two identical $2 \mathrm{~m}^{2}$ PVT collectors with monocrystalline solar cells produced by Racell Technologies were mounted on a free standing concrete wall. One panel was mounted directly in contact with the wall; the other panel was installed with $10 \mathrm{~mm}$ Styrofoam between the PVT collector and the concrete wall. The PVT panels were mounted vertically and were oriented facing south-west, as shown in Fig. 1. Measurements were taken from June to August 2019, at the test facility of the Technical University of Denmark (DTU).

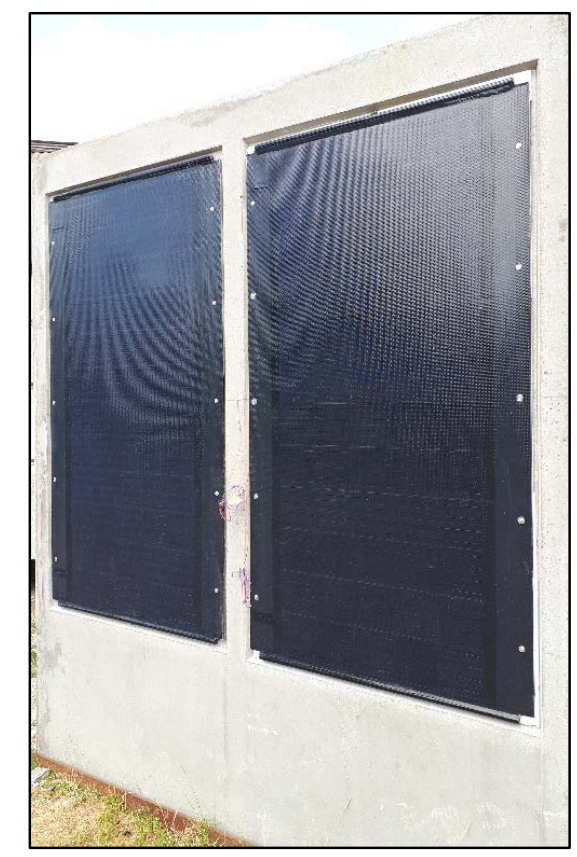

Fig. 1: PVT collectors integrated into a concrete facade.

The pipes to and from the PVT collector were connected to a test rig where the forward temperature was controlled with a heating and cooling system. The equipment setup for maintaining a constant forward temperature to the panel is illustrated in Fig. 2. The collectors were tested with four different operating temperatures; namely $15,20,25$ and $30^{\circ} \mathrm{C}$. The flow rate was kept constant through all the measurement period at 0.045 litre $^{-1}$ for each panel. 


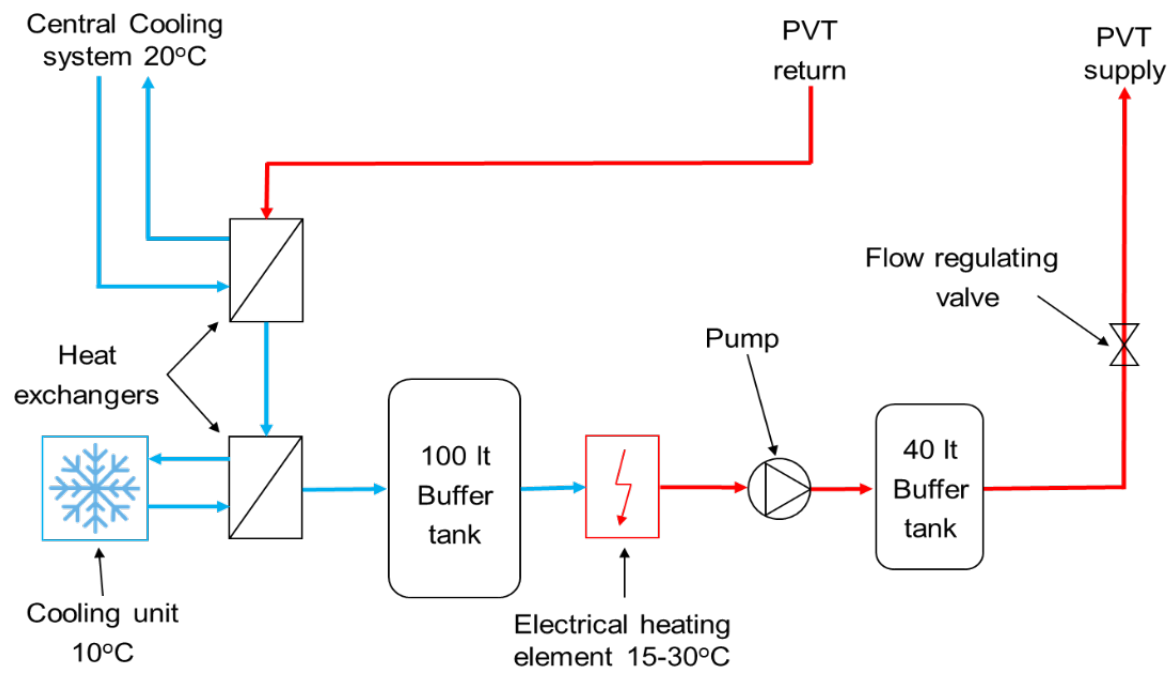

Fig. 2: Equipment setup for keeping constant forward temperature.

The electrical output from the PVT panels, the total and long-wave irradiance as well as the ambient temperature were measured. The temperature differences between the inlet and outlet temperatures to and from the thermal absorbers were measured using thermopiles and the flow rates through the absorbers were likewise measured. Since it was expected that the wall temperature would affect the thermal performance of the panels, the temperature inside the wall behind each of the panels was also measured. The sections of concrete wall behind the PVT panels were $100 \mathrm{~mm}$ thick. Behind the center of each panel, in the middle of the wall (50 mm into the concrete) the temperatures of the wall sections were measured. The wind speed near the PVT panel was measured with an ultrasonic wind sensor mounted in the same plane as the PVT collector as it can be seen in Fig. 3.

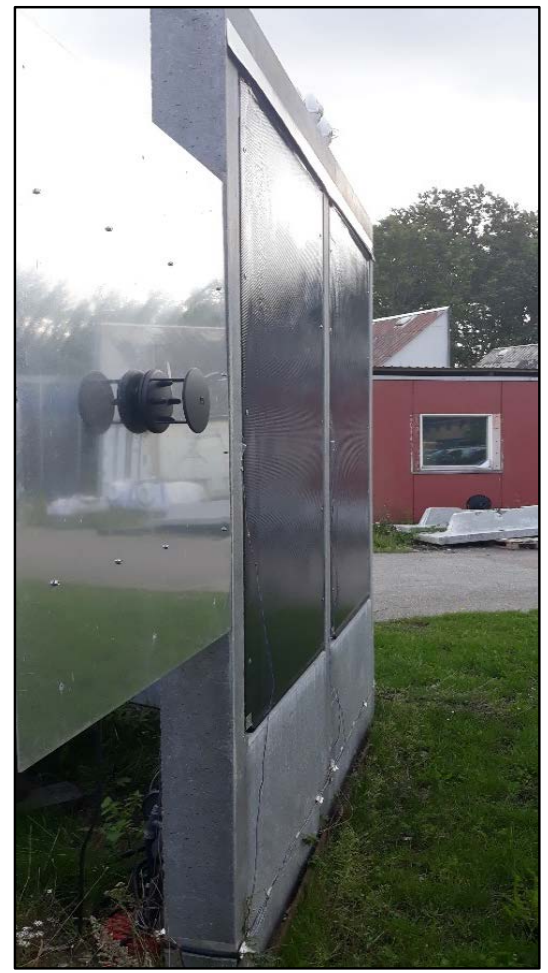

Fig. 3: Location of the ultrasonic wind sensor. 


\subsection{Standard quasi-dynamic test method}

The thermal performance of the PVT collector is normally characterized using the quasi-dynamic test (QDT) method as it is described in ISO 9806:2017 (ISO 9806:2017(E), 2017), using (eq. 1).

$$
\begin{gathered}
\dot{Q}=A_{G}\left[\eta_{0, b} K_{b} G_{b}+\eta_{0, b} K_{d} G_{d}-\alpha_{1}\left(\vartheta_{m}-\vartheta_{a}\right)-a_{2}\left(\vartheta_{m}-\vartheta_{a}\right)^{2}-a_{3} u^{\prime}\left(\vartheta_{m}-\vartheta_{a}\right)+a_{4}\left(E_{L}-\sigma T_{a}^{4}\right)-\right. \\
\left.a_{5}\left(d \vartheta_{m} / d t\right)-a_{6} u^{\prime} G-a_{7} u^{\prime}\left(E_{L}-\sigma T_{a}^{4}\right)-a_{8}\left(\vartheta_{m}-\vartheta_{a}\right)^{4}\right] \\
u^{\prime}=u-3
\end{gathered}
$$

In this paper, a modified version of (eq. 1) was used, utilizing the global irradiance on the collector plane and the incidence angle modifier, as presented in (eq. 3) and (eq. 4). The coefficients for the collectors' performance were calculated at maximum power point tracking (MPPT) operation.

$$
\begin{gathered}
\dot{Q}=A_{G}\left[\eta_{0, b} K_{\theta} G_{t}-a_{1}\left(\vartheta_{m}-\vartheta_{a}\right)-a_{2}\left(\vartheta_{m}-\vartheta_{a}\right)^{2}-a_{3} u^{\prime}\left(\vartheta_{m}-\vartheta_{a}\right)+a_{4}\left(E_{L}-\sigma T_{a}^{4}\right)-a_{5}\left(d \vartheta_{m} / d t\right)-\right. \\
\left.a_{6} u^{\prime} G-a_{7} u^{\prime}\left(E_{L}-\sigma T_{a}^{4}\right)-a_{8}\left(\vartheta_{m}-\vartheta_{a}\right)^{4}\right] \\
K_{\theta}=1-b_{0}\left(\frac{1}{\cos \theta_{i}}-1\right)
\end{gathered}
$$

\subsection{Extended quasi-dynamic method}

The wall on which the PVT panels are integrated, can be heated up (or cooled down) by the ambient temperature, the solar irradiance and the panel temperature and this can increase or decrease the efficiency of the PVT. For this reason, it was decided to perform two analyses using the QDT method. The first method applied was the standard QDT formula as presented in (eq. 3) and the second one was an extended version of the QDT equation, where a new term $\left(\alpha_{9}\right)$ was added, which would take into consideration the temperature of the wall compared to the mean temperature of the PVT. The extended QDT equation is presented in (eq. 5).

$$
\begin{gathered}
\dot{Q}=A_{G}\left[\eta_{0, b} K_{\theta} G_{t}-a_{1}\left(\vartheta_{m}-\vartheta_{a}\right)-a_{2}\left(\vartheta_{m}-\vartheta_{a}\right)^{2}-a_{3} u^{\prime}\left(\vartheta_{m}-\vartheta_{a}\right)+a_{4}\left(E_{L}-\sigma T_{a}^{4}\right)-a_{5}\left(d \vartheta_{m} / d t\right)\right. \\
\left.-a_{6} u^{\prime} G-a_{7} u^{\prime}\left(E_{L}-\sigma T_{a}^{4}\right)-a_{8}\left(\vartheta_{m}-\vartheta_{a}\right)^{4}-a_{9}\left(\vartheta_{m}-\vartheta_{w}\right)\right]
\end{gathered}
$$

\section{Results}

\subsection{Measurement results}

The electrical power produced by the two panels along with the solar irradiance on the panels' surface is illustrated in Fig. 4 for the $27^{\text {th }}$ of June. It can be observed that the uninsulated panel produced slightly more electricity than the insulated one. This phenomenon was observed for all the measurement days according to Tab. 5. However, it has to be pointed out that the absolute difference of the average daily electrical output of the two panels was only about $0.5 \%$. 


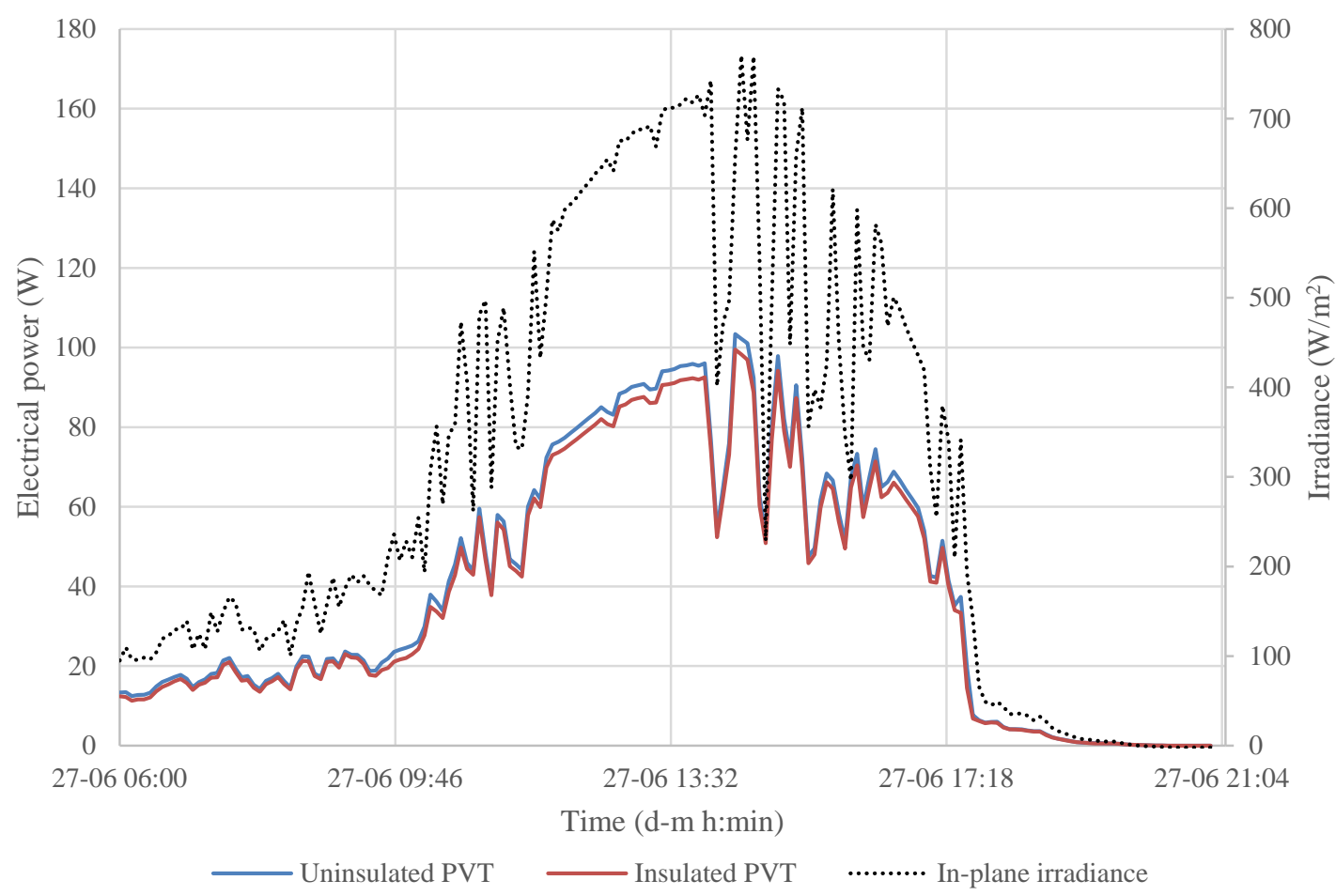

Fig. 4: Electrical power and tilted irradiance for 27/06/2019.

Tab. 1: Average daily electrical efficiencies.

\begin{tabular}{|c|c|c|c|}
\hline & $\begin{array}{c}\text { Non-insulated panel } \\
\text { electrical efficiency (\%) }\end{array}$ & $\begin{array}{c}\text { Insulated panel } \\
\text { electrical efficiency (\%) }\end{array}$ & Abs. difference (\%) \\
\hline $27-06-2019$ & 13.4 & 12.9 & 0.5 \\
\hline $03-07-2019$ & 13.6 & 13.1 & 0.5 \\
\hline $05-07-2019$ & 13.4 & 12.9 & 0.5 \\
\hline $09-07-2019$ & 13.5 & 13 & 0.5 \\
\hline $10-07-2019$ & 13.6 & 13.1 & 0.5 \\
\hline $11-07-2019$ & 13.4 & 12.8 & 0.6 \\
\hline $16-07-2019$ & 14.1 & 13.5 & 0.6 \\
\hline $23-07-2019$ & 13.9 & 13.3 & 0.6 \\
\hline $28-07-2019$ & 13.3 & 12.9 & 0.4 \\
\hline $16-08-2019$ & 13.9 & 13.3 & 0.6 \\
\hline
\end{tabular}

The reason for this difference in electrical output was the different temperature of each panel. In Fig. 5, the outlet fluid temperature of the two panels is presented along with the fluid inlet temperature and the irradiance on the panels' surface. The inlet fluid temperature was the same for the two panels. It can be seen that the outlet fluid temperature of the insulated panel is always higher than the uninsulated one, for periods of the day where the panel is heated by the sun. However, in the afternoon, where the irradiance on the panels' surface drops rapidly, it can be seen that the outlet temperature of the uninsulated panel is higher than the insulated one. This phenomenon was observed through all the measurement days with high irradiance. 


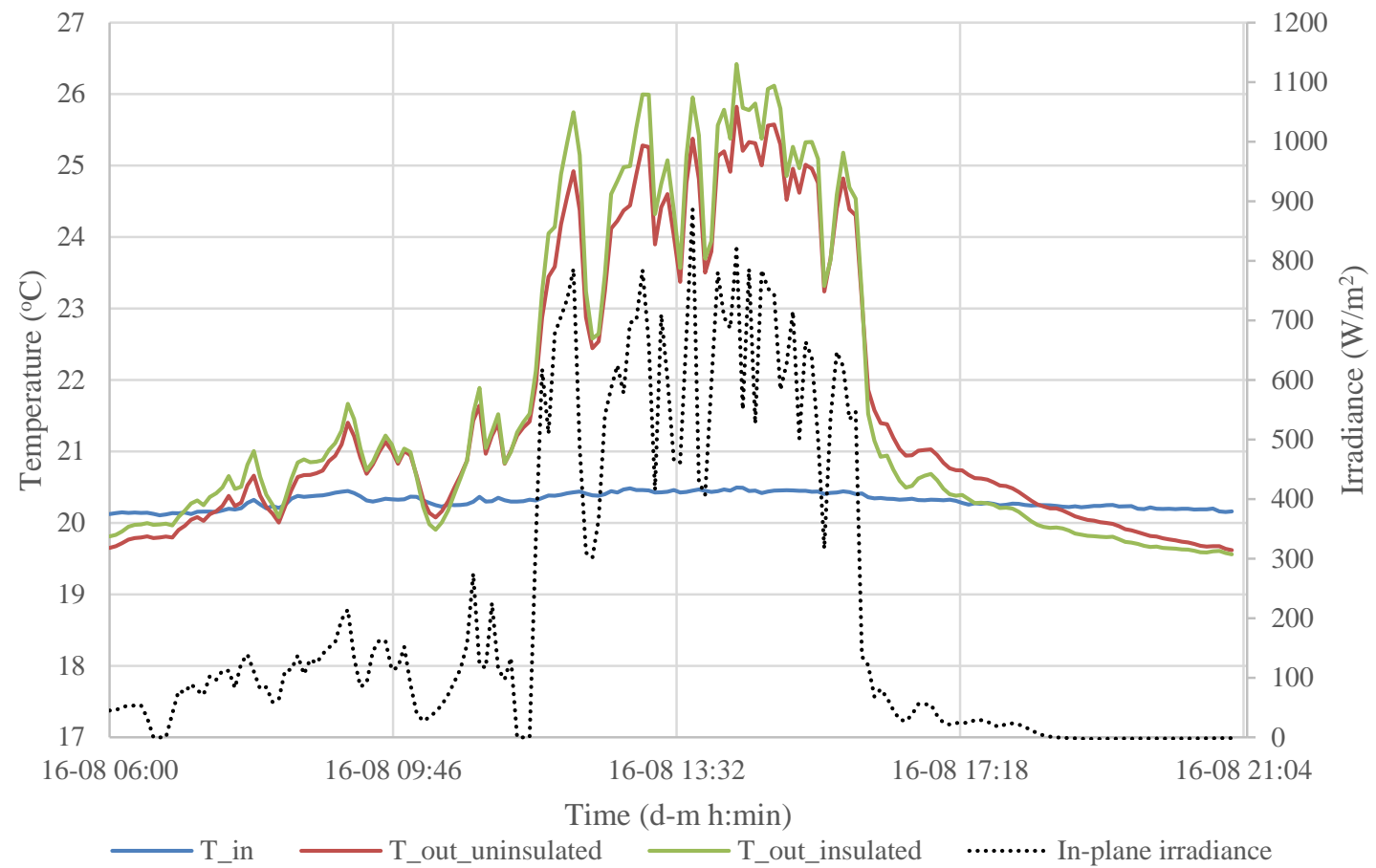

Fig. 5: Inlet and outlet fluid temperature and tilted irradiance for 16/08/2019.

A possible explanation of this behavior is given in Fig. 6 where the wall temperature behind the insulated and the uninsulated panel is presented along with the mean temperature of the two panels. It can be observed that the wall temperature behind the uninsulated panel reached much higher levels, being affected by the mean temperature of the panel and the irradiation. The temperature of the wall varied behind the two panels approximately $2-4 \mathrm{~K}$ over the day. In the afternoon, the wall discharged its heat to the panel increasing its mean temperature. This effect is much more significant for the uninsulated panel because there is no insulation to reduce the heat transfer, but also because of the higher wall temperature. This behavior was observed for all measurement days with high irradiance.

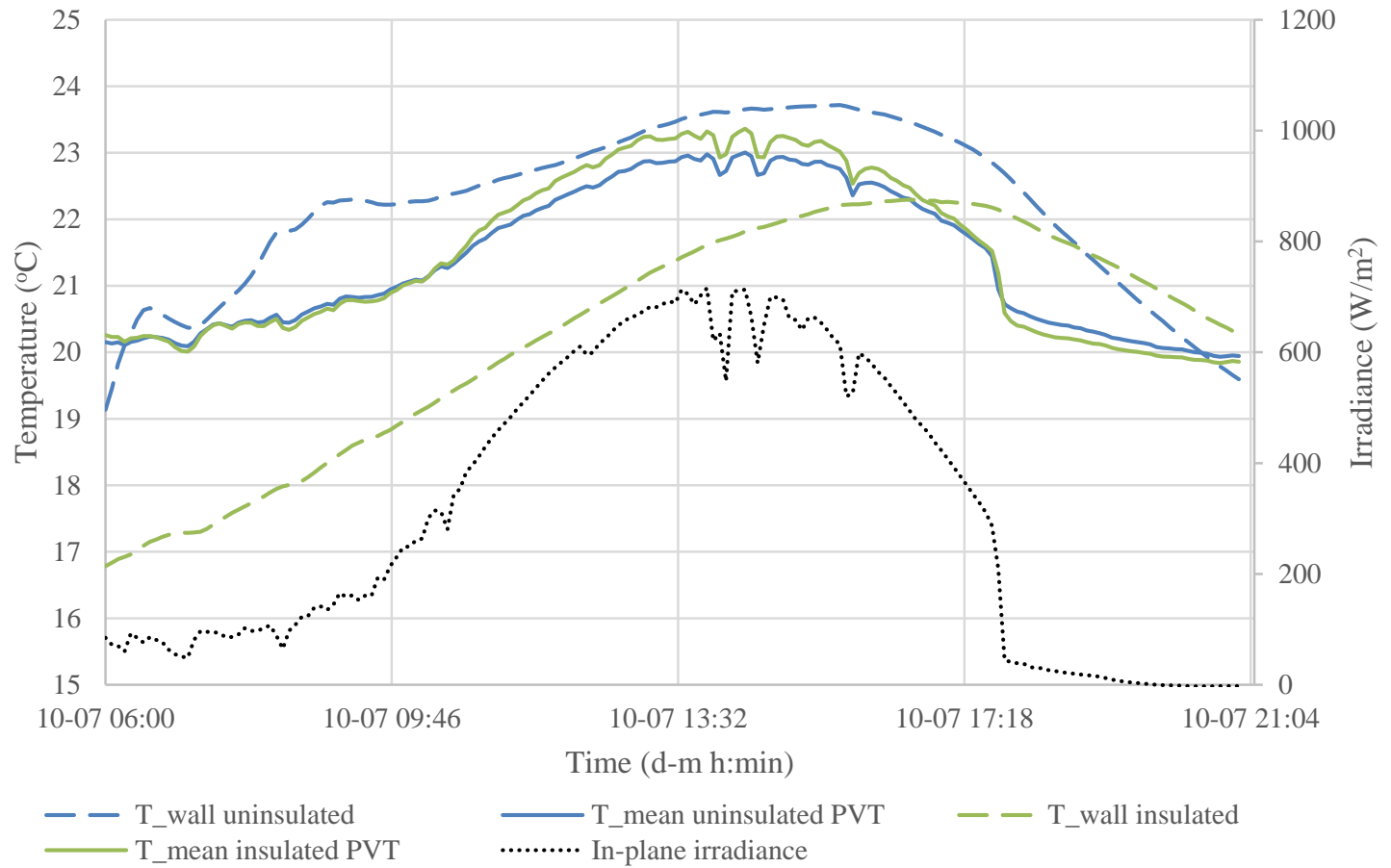

Fig. 6: Wall and mean panel temperatures and tilted irradiance for 10/07/2019. 


\subsection{Quasi-dynamic test results}

Applying the two versions of the QDT equations, the thermal performance of the uninsulated panel was calculated. The calculated thermal output from the standard and the extended QDT is reported in Tab. 2 and the obtained coefficients from the two methods are reported in Tab. 3.

Tab. 2: Thermal performance results for uninsulated PVT.

\begin{tabular}{|c|c|c|c|c|c|c|c|c|}
\hline \multirow[b]{2}{*}{ Date } & \multirow[b]{2}{*}{$\begin{array}{l}\text { Start } \\
\text { time }\end{array}$} & \multirow[b]{2}{*}{$\begin{array}{l}\text { End } \\
\text { time }\end{array}$} & \multirow[b]{2}{*}{$\begin{array}{c}\mathbf{T}_{\text {in }} \\
\left({ }^{\circ} \mathrm{C}\right)\end{array}$} & \multirow[b]{2}{*}{$\begin{array}{c}\text { Measured } \\
\text { thermal } \\
\text { output } \\
\text { (kWh) }\end{array}$} & \multicolumn{2}{|c|}{ Standard QDT } & \multicolumn{2}{|c|}{ Extended QDT } \\
\hline & & & & & $\begin{array}{c}\text { Modelled } \\
\text { thermal } \\
\text { output } \\
\text { (kWh) }\end{array}$ & $\begin{array}{c}\text { Deviation } \\
(\%)\end{array}$ & $\begin{array}{c}\text { Modelled } \\
\text { thermal } \\
\text { output } \\
\text { (kWh) }\end{array}$ & $\begin{array}{c}\text { Deviation } \\
(\%)\end{array}$ \\
\hline $27-06$ & $12: 00$ & $17: 00$ & 30 & 3.27 & 2.95 & -9.9 & 3.16 & -3.4 \\
\hline $03-07$ & $12: 00$ & $15: 00$ & 25 & 1.96 & 2 & 2.3 & 1.98 & 1.4 \\
\hline $05-07$ & $11: 00$ & $14: 00$ & 25 & 2.2 & 2.3 & 4 & 2.28 & 3.1 \\
\hline $09-07$ & $11: 00$ & $16: 00$ & 20 & 4.28 & 4.21 & -1.7 & 4.5 & 5 \\
\hline $10-07$ & $10: 00$ & $16: 00$ & 20 & 5.94 & 5.87 & -1.2 & 5.87 & -1.2 \\
\hline $11-07$ & $10: 00$ & $14: 00$ & 20 & 3.95 & 4.03 & 1.9 & 3.98 & 0.7 \\
\hline $16-07$ & $11: 00$ & $16: 30$ & 15 & 6.78 & 6.81 & 0.4 & 6.87 & 1.2 \\
\hline $23-07$ & $10: 00$ & $17: 00$ & 15 & 8.79 & 8.44 & -4 & 8.62 & -1.9 \\
\hline $28-07$ & $12: 30$ & $16: 00$ & 30 & 2.74 & 2.84 & 3.7 & 2.66 & -2.6 \\
\hline $16-08$ & $12: 00$ & $16: 00$ & 20 & 4.28 & 4.32 & 0.9 & 4.22 & -1.5 \\
\hline
\end{tabular}

Tab. 3: Collector coefficients from quasi-dynamic testing (based on gross area).

\begin{tabular}{|c|c|c|c|c|}
\hline & \multicolumn{2}{|c|}{ Standard QDT } & \multicolumn{2}{c|}{ Extended QDT } \\
\cline { 2 - 5 } & Coefficients & t-scores & Coefficients & t-scores \\
\hline$\eta_{0, \mathrm{~b}}(-)$ & 0.59 & 24 & 0.53 & 27 \\
\hline $\mathrm{b}_{0}(-)$ & 0.12 & 15 & 0.14 & 21 \\
\hline$\alpha_{1}\left(\mathrm{~W} \mathrm{~m}^{-2} \mathrm{~K}^{-1}\right)$ & 17.7 & 68 & 7.1 & 12 \\
\hline$\alpha_{5}\left(\mathrm{~J} \mathrm{~m}^{-2} \mathrm{~K}^{-1}\right)$ & $4.4 * 10^{4}$ & 32 & $3.9 * 10^{4}$ & 35 \\
\hline$\alpha_{6}\left(\mathrm{~m}^{-1} \mathrm{~s}\right)$ & 0.06 & 6 & 0.06 & 8 \\
\hline$\alpha_{9}\left(\mathrm{~W} \mathrm{~m}^{-2} \mathrm{~K}^{-1}\right)$ & - & - & 24.8 & 20 \\
\hline
\end{tabular}

Adding the new term in the QDT equation changed all the coefficients calculated from QDT except of the value of $\alpha_{6}$. Coefficient $\alpha_{9}$ takes into account the heat losses (or heat gains) from the panel to the wall and seems to be very significant from a statistical point of view (high t-score). This new coefficient leads to a reduction of $\alpha_{1}$, which is due to the fact that the heat losses to the wall are taken into account by coefficient $\alpha_{9}$. The decrease of coefficient $\alpha_{5}$ was not anticipated and is thought to be caused by the interplay of the thermal mass of the wall and is changed due to the addition of coefficient $\alpha_{9}$. In theory, the introduction of coefficient $\alpha_{9}$ should not have any effect on the $\eta_{0, b}$ and $b_{0}$ coefficients. However, both coefficients changed with the introduction of the new factor. It is not clear at the moment if the standard or the extended formula calculates more accurately the results and more investigations have to be conducted. It has to be pointed out though that the deviation of the daily calculated values for the extended formula of QDT are smaller, suggesting that, in 
general, it calculates more accurately the thermal performance of the panel. The suggested extended version of QDT was also applied to the insulated panel. In that case, the t-score of $\alpha_{9}$ coefficient was below 3, so it was considered insignificant, proving that, in the case of the insulated panel, the wall temperature does not affect the thermal performance. This result enhances the belief that the addition of $\alpha_{9}$ coefficient was necessary in the QDT formula.

As the temperature of the wall behind the panels only was measured at one location behind the center of each PVT panel, there may be some uncertainty in how well the measured temperature represents the average wall temperature. Further, as seen in the measurement, the sections of wall behind each panel had different temperature developments and as the PVT panels were mounted next to each other on a continuous wall with only a few centimeters apart, there may be some heat transfer between the wall sections behind each of the panels. It is nevertheless believed that the added coefficient $\alpha_{9}$ is significant and should be considered for collectors in contact with substantial thermal mass. To determine a more precise value for $\alpha_{9}$ it should be considered to design the experiment where the collectors are tested individually and the influence of nearby collectors is eliminated.

\section{Conclusion}

In this study, two façade integrated PVT panels were investigated in terms of thermal performance. One of them had a layer of insulation between the panel and the wall and the other was in direct contact with the wall. It was found that the insulated panel had higher thermal performance than the uninsulated one, as higher outlet fluid temperatures were reached. On the other hand, due to lower temperature of the panel, the uninsulated one had higher electrical performance. It was pointed out that the wall affected significantly the thermal performance of the panel, especially of the uninsulated panel, since it created additional heat losses or heat gains to the panel. For this reason, a new factor was suggested to be used in the standard QDT formula that takes into account the wall temperature. The obtained results for this new coefficient justified this addition, showing a considerable statistical importance of the new coefficient. It has to be mentioned that for the insulated panel the new coefficient was statistical insignificant as was to be expected. However, although the extended QDT formula showed promising results in term of modelling of thermal performance of the panel, more investigations are considered necessary in order to reach a final conclusion on whether this factor should be added to the standard QDT formula.

\section{Acknowledgement}

The research was financed by the Danish Energy Agency through EUDP grant no. 64017-05157, Fonden af 20. December journal no 155808-15-JAS and Martha og Paul Kerrn-Jespersens Fond.

\section{References}

Aste, N., del Pero, C., Leonforte, F., 2014. Water flat plate PV-thermal collectors: A review. Sol. Energy 102, 98-115. https://doi.org/10.1016/j.solener.2014.01.025

Butera, F., Adhikari, R.S., Aste, N., Braceo, R., 2007. Solar hybrid Photovoltaic-Thermal (PVT) façade for heating, cooling and electricity generation. 2007 Int. Conf. Clean Electr. Power, ICCEP '07 766-769. https://doi.org/10.1109/ICCEP.2007.384300

Dannemand, M., Perers, B., Furbo, S., 2019. Performance of a demonstration solar PVT assisted heat pump system with cold buffer storage and domestic hot water storage tanks. Energy Build. 188-189, 46-57. https://doi.org/10.1016/j.enbuild.2018.12.042

ISO 9806:2017(E), 2017. Solar energy - Solar thermal collectors - Test methods, 2nd edition.

Kramer, K., Helmers, H., 2013. The interaction of standards and innovation: Hybrid photovoltaic-thermal collectors. Sol. Energy 98, 434-439. https://doi.org/10.1016/j.solener.2013.08.042 